\title{
BRITISH CORPORATE LAW REFORM
}

CORPORATE law, which regulates the heart of a nation's economy, has recently been subjected in Great Britain to a detailed re-evaluation by the Report of the Committee on Company Law Amendment. ${ }^{2}$ Established to explore the deficiencies that eighteen years of experience have demonstrated in the Companies Act of $1929,{ }^{2}$ the Cohen Committee ${ }^{3}$ has made recommendations touching virtually every field of corporate regulation. ${ }^{4}$ Though sponsored in legislative form by the Labor Party, the Report, initiated under the wartime Conservative Party, contains no reference to the socialized segment of the British economy and is without suggestion of a doctrinal attack on the limited liability system.

The Companies Act of 1929 substantially combines in its scope the functions performed by our state corporation laws and by the federal acts administered by the Securities and Exchange Commission. Unlike the federal enactments, however, it affects all aspects of virtually all corporate businesses; and unlike the far from uniform state laws, it provides a unified statute which parallels our federal laws in the extent of regulation.

The basic problem confronting the Committee arises from the redistribution of power and wealth resulting from a broadened base of corporate ownership. In England as in the United States widely dispersed small shareholdings have replaced the entrepreneurial stock participation of earlier years. 5 The disproportionate power thus vested in a management divorced from ownership makes imperative the most enlightened supervision and regulation.

1. Cmd. 6659 (hereinafter cited as REFORT). The Report consists of a series of tersely discussed amendments which stress, as problems to which public attention has particularly been drawn, prospectuses, nominee shareholdings, accounting, and "control." Excluded from the scope of the amendments are questions of general economic policy and special war time legislation. REPORT $\S \S 1,3,7$.

2. $19 \& 20$ Geo. V, c. 23. For a concise description of the history of the Companies Acts see Horrwitz, Historical Deciolopment of Company Laz, 62 L. Q. REv. 375 (1946).

3. The Committee of thirteen experts was chairmanned by Mr. Justice Cohen of the King's Bench Division of the Supreme Court of Judieature and is popularly referred to as the Cohen Committee. Appointed in 1943, the Committee held 47 meetings before submitting its Report in June, 1945. REFORT $\$ 4$.

4. The proposed amendments, substantially incorporatcd into a Companies Eill, have been passed by the House of Lords and by the House of Commons as this Comment went to press. See 441 H. C. Deb. 172 (5th Ser. 1947).

5. "This tendency is growing at the present time, and the number of shareholders is likely to increase further, with a corresponding diminution in the size of the ayerage shareholding." REPORT $\$ 124$. The statistics of ten typical companies presented in the $R c-$ port show an average of $41 \%$ of the stockholders each holding less than 100 shares, $67 \%$ less than 200 shares, and $88 \%$ less than 500 shares. Ihid. Sce generally, Gruray, Sunver of Shareholdings in 1,710 Corporations With Securities Listed on A Ninto:al Securites Exchange (TNEC Monograph 30, 1941); Benle and Mesirs, Tne Moners Corporation and Private Property (1932). 
The Report has followed traditional lines in that disclosure of adequate information is the chief technique proposed to facilitate supervision by aggressive stockholders as well as by the government. In addition, the disclosure provisions are designed to increase the rational element in investments and to dispel the secrecy which might sap public confidence in the limited liability system. With equal emphasis, higher standards of fiduciary conduct are defined for directors and more stringent means of enforcement recommended. 6

In order to compare the legislative techniques suggested by the Report with analogous American statutes the more important of the proposed amendments have been grouped below under the generic classifications of general corporate organization, supervision of stock, the position of directors, and ' stockholders' control. ${ }^{7}$

\section{CORPORATE ORganization}

The Committee expressed satisfaction with the conscientious management of the vast majority of limited companies and predicated the welfare of the national economy as a whole upon its continuation. Corporate organization was therefore left fundamentally unchanged, and suggested reforms directed mainly towards classification of obligations within existing institutional relationships.

Ultra Vires. The Committee's initial recommendation is a frontal attack on ultra vires. The doctrine has proved an unnecessary pitfall for creditors of a corporation, who, unless the corporation has charter powers for the activity involved, may have no legal rights of recovery. ${ }^{8}$ Conversely, the existing practice of drafting charters to include any foreseeable business ${ }^{0}$ may make illusory the doctrine's protection to stockholders.

6. The Committee would also afford a division of labor between legislative regulation of the Companies Act and administrative control through the London Stock Exchange Council and the Board of Trade. The Stock Exchange Council is a non-governmental body similar to the New York Stock Exchange Committee, while the Board of Trade is the governmental department of commerce.

7. The relatively minor recommendations on mortgages and charges (REPORT $\$ \$ 61$ 71) and on liquidations (REPoRr $§ \S 142-53$ ) are not discussed. Also omitted are the scetions on the particularly British classification of "private" companies (REPORT $\$ \S 47-60$ ). A private company is defined by $\S 26$ of the Companies Act as one which (a) restricts the transfer of its shares; (b) limits its shareholders to fifty; and (c) prohibits any solicitation to the public for shares or debentures of the Company.

8. "For example, if a company which has not taken powers to carry on a taxi-cab service, nevertheless does so, third persons who have sold the taxi-cabs to the company ... may have no legal right to recover payment from the company. ... (A)s now applied to companies, the ultra vires doctrine serves no positive purpose but is, on the other hand, a cause of unnecessary prolixity and vexation." REPORT $\$ 12$.

9. See Cotman v. Brougham, [1918] A.C. 514, esp. the opinion of Lord Wrenbury at 521 ; SEC, Report on the Study and Investigation of the Work, Activities, Person- 
To abolish the doctrine it is proposed that "every company . . . should . . . have as regards third parties the same powers as an individual," "a formula followed only in the most advanced American statutes. In the future charters are to be solely stockholder-corporation contracts concerning the powers of directors. With such reform charter amendment is rendered possible by special resolution only. ${ }^{11}$

Trade Names. The Report proposes to eliminate litigation over deceptively similar corporate trade names by giving an administrative body discretion to approve all names. This discretionary power, to be vested in the registrar of companies, would be appealable exclusively to the Board of Trade. ${ }^{12}$ The constitutionality of a similar provision has recently been upheld in Illinois against the attack of unlawful delegation of power without adequate legislative standards. ${ }^{13}$

nel and Functions of Protective and Reosganization Cossmitess, pt. VII, 479 (1938).

10. REPORT $\S 12$. The proposal appears substantially that of the National Conference of Commissioners on Uniform State Laws and Proceedings, Moder. Busniess Conronatro:; Acr $\$ \S 10,11$. A minority of states have similarly undertaken statutory modifieation of the doctrine. CAL. Civ. Code $\$ 345$ (Deering, 1941); ID.uno Laws Ansi. \$29-114 (1943);

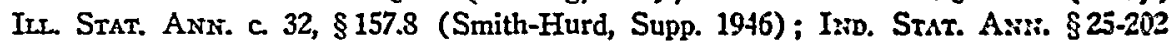
(Burns, 1933); Kan. Gen. Stat. \$17-3001 (Corrick, Supp. 1945); LA. Ger. Stat. \$1092 (Dart, 1939); Mirch. Stat. Awn. \$21.11 (1938); Mins. Stat. \$\$7492-10, 11 (Mason, Supp. 1940); MoNt. Rev. Codes $\$ 5994$ (1935) as amended by Laws 1947, c. 39; Neb. Rev. Stat. \$21-1, 117 (1943) ; Ohio GeN. Code \$ 8623-\$ (Page, 193\$) ; PA. Stat., tit. 15, $\$ 2852-303$ (Purdon, 1938); VT. Pur. Laws $\$ 5817$ (1933); Wasm. Rev. Stat. \$ 3803-11 (Remington, Supp. 1940). Kansas had already approzched its reform by judicial construction. Harris v. Independence Gas Co., 76 Kan. 750, 92 Pac. 1123 (1907).

For reluctance to desert precedent and use the new ireedom see MlacQueen v. The Dollar Saving Bank Co., 133 Ohio St. 579, 15 N.E.2d 529 (1938) (Ohio modification discussed but decision based on another ground); Unione Fratellanza Oratinese v. Picciano, 129 Ohio St. 466, 196 N.E. 155 (1935) (doctrine held still available as a defense "under proper circumstances"). The English proposal does not appear to retain the doetrine as against a third person having actual knowledge of the lack of corporate authority. $C f$. however, Ernest v. Nicholls, $6 \mathrm{H}$. L. Cas. 401 (1857). See generally Horrwitz, Company' Law Refornt and the Ultra Vires Doctrine, 62 L. Q. Rev. 66 (1946).

11. The Report has been criticized for not abolishing the dichotomy of memoranda and articles. "There is no reason why ... the whole of a company's constitution should not be embodied in one document instead of two." Kahn-Freund, Company Lrow Reform, 9 MOD. L. Rev. 235, 236-7 (1946). Extension of the principle to public corporations is also questioned. Id. at 237-8.

12. The power of rejection vested in the two administrative bodies would be exercised at registration and before any business unlike practice under the Federal Trade Commission. Discretion would extend to rejection of names which may mislead the public by unwarranted inclusion of the words "bank" or "trust." REFORT $\S \S 15-6$. Our states typieally have a statutory listing of such words. See, for example, N.Y. PExAL IAv $\$ \S 663,665$; N.J. Stat. ANN. \$ $14: 2-3$.

13. Ils. Stat. ANx. c. 32, $\$ 157.148$ (Smith-Hurd, Supp. 1946), Investors Syndieate of America, Inc. v. Hughes, 378 Ill. 413, 38 N.E.2d 754 (1941). The statute specifically provides for appeals from the ruling of the Secretary of State to the courts; cf. N. Y. 
Parent-Subsidiaries. The existing definitions of subsidiaries in the Companies Act suffer from over-emphasis upon direct stock ownership and do not reach sub-subsidiaries. ${ }^{14}$ The Report, following the lead of our federal enactments, proposes control as decisive of the parent-subsidiary relationship. Since a legislative standard is desirable, the Committee defines control as the power to procure the election or removal of a majority of directors of a company either through ownership of any part of the share capital in that company or in any other company, or by any other means as long as some share capital is beneficially owned. Even in the absence of voting control, however, beneficial ownership of over half of the equity share capital would furnish an alternative definition. ${ }^{15}$ The "election" test undoubtedly falls within the dual definition of the Public Utility Holding Company Act (10\% control of voting stock or "controlling influence") ${ }^{16}$ and thus sacrifices some breadth for a presumably more tangible criterion.

For parents and subsidiaries, consolidated balance sheets and profit and loss statements would be required, ${ }^{17}$ and many fine accounting distinctions

GEN. CoRp. LAw \$9. Where statutes prohibit misleading or confusing names, judgment by an administrative body in certifying a certificate of incorporation is not conclusive on the courts. Standard Oil Co. of New Mexico v. Standard Oil Co. of Cal., 56 F.2d 973 (C.C.A. 10th 1932). Indeed, a certificate by a state corporation clerk has been given "110 weight." Eureka Fire Hose Co. v. Eureka Rubber Mfg. Co., 69 N.J.Eq. 159, 60 Atl. 561 (Ch. 1905), aff'd mem. 71 N.J.Eq. 300, 71 Atl. 1134 (Ct. Err. \& App. 1909).

14. $\$ 127$ of the Companies Act defines a subsidiary as a company in which a second company either owns more than $50 \%$ of the issued share capital or voting stock or has the power directly or indirectly to appoint a majority of directors. Apparently the indirect power of appointment has not been considered to reach sub-subsidiaries. See Reront $\$ 116$; 89 SoL. J. 583-4 (1945) ; Kahn-Freund, supra note 11, at 238-9. The present definition is also too broad in some circumstances. Ownership of all of a company's preference capital, if greater than the voting capital, would now make the second company a subsidiary even if not controlled in any way. REPORT $\$ 118$.

15. REPORT pp. 72-3. Although the alternative definition in terms of half ownership of the equity does not fully meet the objection of note 14, stpra, the Committee found that such a concentrated holding might give practical control of the business even without voting control. REPORT $\S 118$.

Power arising only from provisions of a debenture trust deed or by virtue of shares issued for such purpose are excluded as in the 1929 Act. REport p. 72 . CoMpunies Act $\$ 127$ (1) (b). One of the few places in the Report in which American experiences are directly cited is $\S 118$, where the Committee mentions our recognition of control as definitive of the parent-subsidiary relation for accounting purposes.

16. $\$ 2(a)(7)$ and (8), 49 STAT. 803 (1935), 15 U.S.C. $\$ 79 a$ (1940) (hereinafter cited by section number only). See H. M. Byllesby \& Co., 6 S.E.C. 639 (1940), 51 YALE L. J. 1018 (1942). See also $\S 2$ (a) (9) of the Investment Companies Act, 54 Stat. 789 (1940), 15 U.S.C. $\$ 80 a-1$ (1940) (hereinafter cited by section number only) (controlling influence with rebuttable presumption of control arising from beneficial ownership of $25 \%$ of the voting securities). $\$ 2$ (a) (11) of the Public Utility Holding Company Act has the additional classification of an "affiliate" (one definition in terms of $5 \%$ ownership of voting securities). See $\S 2(3)$ of the Investment Companies Act.

17. To the extent that complete consolidation would be misleading, directors are given discretion to adjust the accounts or annex supplemental information. REPORT $\$$ 119-20 
removed by the required elimination of inter-group stock ownership and indebtedness. ${ }^{18}$ Subsidiaries would also be prohibited from purchasing further shares or voting present stock in their parent companies. ${ }^{10}$

Accounts. The necessity for the modernization of accounting requirements, a basic objective of the study, has been recognized by emphasis on greater break-down and intelligibility of individual items. Special attention is paid to reserves which-with calculated financial modesty-have been hidden through a variety of accounting techniques which include the creation of excessive provisions for contingencies, the charge of capital expenditure to revenue, and the use of profits for an excessive write-down of investments, property or machinery. The attention thus paid to the exposure of undisclosed reserves strikes partially at the advantages given to directors in personal dealings in company stock. In addition, conservatism of this type on the balance sheet is equivalent to a non-conservative income statement, since the resultant understatement of depreciation charges and the like will in the future overstate profits. ${ }^{21}$

A legislative differentiation between fixed and current assets is proposed 22 which has potential importance in standardizing these items for ratio analyses. However, only to this extent has uniformity of accounting practice been

and pp. 73-4. Contrary to the proviso in $\$ 126$ of the present Act, it will be necessary to specify the amounts of the profits and losses of any subsidiary in the holding company's account. Ibid. See Murphy, Revision of British Company Lazi, 30 Mrnsx. L. Rxw. 585, 597-9 (1946). Cf. SEC Regulation S-X, Art. 4.

18. REPORT pp. 73-4.

19. $\$ 45$ of the Companies Act would be extended to prohibit a subsidiary from providing money for subscription of its own shares or those of its holding company and to prohibit the subsidiary from buying or providing financial assistance for the purchase of shares of the holding company. An exception is made when shares are held as trustee for others and the present exception in favor of employees continued. REFont $\$ 170$ and pp. $107-8$.

20. "We do not believe that, if fully informed, shareholders would press for excessive dividends. ... It is also important ... to dissipate any suggestion that hidden profits are being accumulated by industrial concerns to the detriment of consumers and those who work for industry." REPORT \$ 101. Compare the opinion of Mr. Justice Buckley in Newton v. Birmingham Small Arms Co., Ltd., [1906] 2 Ch. 378, 387 "The purpose of the balance sheet is primarily to show that the financial position of the company is at least as good as there stated, not to show that it is not or may not be better." See also Stapley v. Read Brothers, [1929] 2 Ch. 1; discussion of Rex v. Kylsant, 23 Crim. App. R. 83 (1931), in MacIntyre, Criminal Prozisions of the Securities Act and Analogies to Similar Criminal Statutes, 43 YALE L. J. 254 (1933) and in 172 L. T. 139, 161 (1931).

21. See generally Kripke, $A$ Case Study in the Relationship of Latv and Accounting, 57 HARv. L. Rev. 433 (1944) ; Kripke, Accountants' Finansial Statements asd Fact-Finding in the Law of Corporate Regulation, 50 YaLE L. J. 1180 (1941). Assurance and Insurance Companies and such trading and discount companies as the Beard of Trade may designate are absolved from showing separately reserves and provisions for depreciation. REPORT $\S 101$.

22. Fixed assets are defined as assets not held for sale or conversion into cash; current assets as cash and assets held for conversion into cash. Refont $\$ 100$ and p. 58. Com- 
imposed; corporations will continue to be able to adapt accounts to the diverse requirements of their business. ${ }^{23}$ The Report also reiterates the recognized objection to the declaration of dividends to the extent of paid-in surplus. ${ }^{24}$

Accompanying the emphasis on accounting is an attempted specification of auditor standards which was noticeably lacking in the 1929 Act. The Board of Trade is to be given power to certify eligible auditors, and employees, directors, or associates may not render such service to their own company. ${ }^{25}$ With the auditors' more dominant functions go a description of minimal duties ${ }^{26}$ and increased powers of inspection and access to meetings. ${ }^{2 i}$

Inspections. The Report would achieve supervision of the revised company

pliance of public utilities companies with this provision is not obligatory. REPORT p. 59. Cf. SEC REgulatron. S-X, Rule 3-13 (current assets are those generally realizable within one year).

23. REPORT $\S 97$. The Committee, discussing accounting requirements, notes that it is where companies are reluctant to make public information that statutory standards are most needed by accountants. See 12 SEC ANs. REP. 118 (1947) "unless accountants can point to legal requirements as to the extent of disclosure they are often unable to insist on a position contrary to that of the management." A recommendation that accountants be supported by the SEC accounting regulations was made in the Commission's report to Congress, Proposal to Safeguard Investors in Unregistered Securities, $H$. $R$ Doc. No. 672, 79th Cong., 2d Sess. 16 (1946).

For recommendations to the Committee by the Institute of Chartered Accountants, see 116 The Accountant 108 (1947); 89 SoL. J. 559, 572 (1945).

24. Share premiums would henceforth be governed by the sections of the Companics Act relating to the reduction of share capital. REPORT $\$ 108$. For American state statutes, see Comment, 49 Yare L. J. 492, 499 n. 24, 25 (1940). Cf. $\$ 12$ (c) of the Public Utility Holding Company Act.

There is no reason to suspect that the English dividend rule of Verner v. General and Commercial Investment Trust, [1894] 2 Ch. 239, is changed. See Katz, Accounting Prob lems in Corporate Distributions 89 U. PA. L. REv. 764 (1941).

25. Report \$110. See SEC General Rules and Regulations under the SeculiTIEs ACT of 1933, Rule 650, 17 CodE FED. ReGs. $\$ 230.650$ (1938); In the Matter of Red Bank Oil Co., Securities Exchange Act of 1933 Release No. 3110, Jan. 4, 1946.

26. The auditors' report is at the minimum to state (a) whether proper books of account have been kept; (b) whether all the information necessary for purposes of the audit has been obtained; (c) whether the accounts are in agreement with the books, and "cxhibit a true and fair view of (1) the state of affairs of the company as of the date of the balance sheet and (2) the profit and loss ... for the period ended on that date;" and (d), in the case of a holding company which has not annexed consolidated accounts, whether the reasons given for not consolidating are satisfactory. REPORT p. 68. Sce, on the standards of auditors, Samues, Shareholders' Money 315-25 (1933) ; Rabel, Auditing Standards and Procedures in the Light of Court Decisions, 42 MICr. L. REv. 1009 (1944).

27. $\$ 134$ of the Companies Act is criticized for weakening the auditors' report since certification may now be made "as shown by the books of the company." It is recommended that each auditor have a right of access to all information and be entitled to require explanations from company executives necessary to the performance of his duty. REPORT P. 68. 
law by an increased authorization of governmental inspections. One weakness of the 1929 Act would be avoided by abolishing the requirement that an applicant for an inspection prove to the Board of Trade the absence of malicious motives. ${ }^{28}$ Where previously applications were received on behalf of one-tenth of the outstanding stock, a group of 200 stockholders would now suffice. ${ }^{29}$ More significantly, the Board of Trade is permitted to proceed on its own motion, if reasonable ground exists to suspect fraud in the promotion of an enterprise, misfeasance in management, the withholding of information from stockholders, oppression by majority stockholders, or if it is in the public interest. ${ }^{30}$

Failure to disclose information needed in an investigation would subject persons responsible to contempt proceedings. ${ }^{31}$ The Board of Trade would now be able to distribute the report of an inspection to the stockholders, or, if necessary, institute civil action in the name of the company against responsible officers. Persons successfully prosecuted would be liable for the expense of the investigation. ${ }^{32}$

Prosecutions. To complement the government's increased investigatory powers the Director of Public Prosecutions would be given greater statutory authority to proceed criminally whenever there is "reasonable cause to believe ... an indictable offense has been committed" without regard to chances of success or to possible expense. ${ }^{33}$ Prosecution of offenses discovered during liquidation, where reluctance to proceed has previously been noticeable, is now stressed. ${ }^{34}$ The Committee considers that a real threat of criminal prosecution will prove a valuable deterrent. ${ }^{35}$

28. REPORT $\S 155$ and p. 101 ; cf. $\$ 135$ of the Companies Act. Ibid.

29. The present requirements are particulariy restrictive when a company is large.

30. The investigation would extend to any parent or subsidiary. It is hoped that posing the power to inspect would cause companies to meet stockholder grievanees. Repors \$156. Cf. Securtries Act \$8(e), 4 S Stat. 74 (1933), 15 U.S.C. \$77a (1940) (hercin-

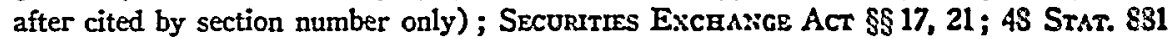
(1934), 15 U.S.C. \$78a (1940) (hereinafter cited by section number only); Pusuc Uturty Holding Cosspany Act §18. For state statutes see N.Y. Ge:. Bus. LAw §352 (power of attorney-general to investigate); ILI. SrAT. Awx. c. 1211/2, 105 (Smith-Hurd, Supp. 1946) (power to inspect, and technique of coordination with the Securities Aet on accountant's certification of data).

31. REPORT p. 102.

32. Wide discretion would be given the court in assessing the costs of investigations which would become a first charge on any amounts recovered. REront $\$ \$ 157-\$$.

33. REPORT p. 106.

34. REPORT \$151. The Committee noted a five year period during which only three public prosecutions were undertaken out of thirty-two reported cases. Ibid. Cf. $\$ 277$ of the Companies Act.

The Report also suggests that since the usual indictment for fraud practiced by more than one person is conspiracy, the present maximum penalty of two years be increased. REPORT $\S 165$.

35. REPORT $\$ 161$. Related sections in American laws are discussed in MacIntyre, 


\section{SUPERvision OF STOCK}

In its supervision of stocks, the Companies Act of 1929 provides the English counterpart to the Securities and Securities Exchange Acts and our state Blue Sky Laws. Its controls are supplemented by the London Stock Exchange Council, which imposes, apart from statute, its own requirements as a condition of dealing on England's largest exchange.

Prospectuses. As a means of presenting information to the investor, the Companies Act has specifically emphasized the prospectus, which is broadly defined as any document by which an offer for sale of shares is made to the public. ${ }^{36}$ Under existing law a company can proceed to an allotment of shares immediately upon the publication of the prospectus. Since such a practice allows insufficient time for press comment or expert advice, a compulsory minimum of two days is proposed between publication of the prospectus and the receipt of subscriptions. ${ }^{37}$ The additional time would also permit strengthened requirements on the disclosure of material contracts, which now include only the dates and names of the parties and the availability of the contracts for inspection. The Report, finding that the inclusion of a summary of material contracts would make prospectuses inordinately bulky, compromises by suggesting that the general nature of the contracts be described ${ }^{38}$ and that the contracts be delivered to the registrar of companies for public in'spection. ${ }^{39}$ The Committee goes outside its field to suggest that, considering the value of publicity (as contrasted with disclosure only), the law of libel might be relaxed to permit freer press comment. ${ }^{40}$

Under the normal method of flotation, prospectuses contain a statement that permission to deal on a stock exchange has or will be undertaken. If permission is refused or deferred after subscriptions are taken and an allotment made, the securities are rendered practically unmarketable. A partial solution is advanced by making application for permission mandatory within

supra note 20; Herlands, Criminal Law Aspects of the Securities Exchange Act of 1934, 21 VA. L. Rev. 139 (1934). Cf. N. Y. GeN. Bus. Law § 353.

36. CoMpanies Acr $\S 380$. The essentials are an offer by the company to the public. A circular addressed to shareholders is not regarded as a prospectus, even if the invitation to invest can be renounced in favor of others. Id. $\$ 35(3)$. "Placings" which amount to offers to the public would now be within the definition. REPoRT $\$ 22$. Compare $\$ 2(10)$ of the Securities Act which provides that a communication is not deemed a prospectus if a prospectus is sent to the individual concerned, or if a statement is made explaining from whom a prospectus can be obtained, and does no more than identify the security, its price and the persons by whom orders will be executed.

37. Report $\$ 27$ and p. 19. Cf. Securities Act $\$ 8$ (20 day period).

38. Report $\$ 31$ and p. 20. Compare Schedule IV, pt. $1, \S 13$ of the Companies Act, as changed, with the similar wording of Schedule A(24) of the Securities Act 48 STAT. 88 (1933), 15 U.S.C. $\$ 77 a a$ (1940) (hereinafter cited as Schedule A).

39. Though material contracts are now made available, at a reasonable time and place, the lack of time for inspection had rendered the provision of little value to investors, and the contracts have not been made readily available for future reference. REPORT $\$ 31$.

40. REPORT $\$ 26$. 
48 hours after the issue of a prospectus, ${ }^{41}$ and by making a declaration that permission had been granted, or at least not refused, a prerequisite to the start of a new enterprise. ${ }^{42}$ The cost of property to promoters as well as the sale price to the company is to be disclosed by a short account in the prospectus of all property transactions to which the funds received from the issue are to be applied provided any director, proposed dircetor, or promoter was directly or indirectly interested. ${ }^{43}$

The Report has given attention to auditors' reports and accounting in prospectuses. It would now become a statutory obligation to include a report of a company's assets and liabilities. ${ }^{4}$ Profits, now given for three years preceding the issue, would be disclosed for five, ${ }^{45}$ and auditors would be under obligation to make any statement necessary for the accuracy of a prospectus. Holding companies' profit and loss statements would be made for the group as a unit. ${ }^{46}$

Civil Liability for Prospectuses. Section 37 of the Companies Act, providing civil liability for false statements in prospectuses, is the forerunner of Section 11(a) and (b) of the Securities Act of 1933. ${ }^{4 i}$ Section 3i, however, does not at present expressly recognize that omissions of material information are frequently as misleading as untrue statements. Nonetheless, English courts have been liberal in using the overall impression of a statement as a criterion of falsity or deceptive truth, ${ }^{48}$ an interpretation approved in

41. If permission to deal is refused within 21 days, allotments would be canceled and subscriptions returned. RFPORT $\$ 28$ and p. 19.

42. The London Stock Exchange Council may defer action on an applieation until after the issue of the first report where the proposition is of a speculative nature. Reross $\S 28$.

43. REPORT $\$ 30$ and p. 20. Cf. Schedule A(20). The remaining recommendations appear to have been anticipated by the Securities Act.

44. REPORT $\$ 37$ and pp. 21-2. For state statutes sce Kix. GEn. Star. $\$ 17-701$ (Corrick, 1935) ; Mass. Stat. Ann. c. 156, $\$ 47$ (1932) ; AIrcri. Stat. A:is. \$\$21.82-.91 (Supp. 1946).

45. REPORT $\$ 32$; cf. Schedule A(26) (3 years).

46. REPORT $\S 21$. By present requirements if any part of the proceeds of an issue is to be applied to the purchase of a company thereby rendered a subsidiary, an accountant's report must be included upon the profits of the company to be acquircd. This regulation would now include control acquired by stock purchase. Reront $\$ 34$ and pp. 21-2; $c$. Schedule A(27).

Corresponding changes to embody the Committee's recommendations would also be made in $\$ \$ 354,355$, dealing with the prospectuses of corporations incorporated outside Great Britain. REPORT pp. 22-3.

47. However, $\S 37$ of the Companies Act contains no equivalent of $\$ 11(\mathrm{e})$ of the Securities Act. See Stevens v. Hoare, 20 T.L.R. 407 (Ch. D. 1904). Nor is there a statutory definition of a standard of reasonableness as in $\$ 11(c)$ of the Securities Act. Sce Adams v. Thrift, [1915] $2 \mathrm{Ch}$. 21. See generally Shulman, Cieril Liability and the Sceuritics Act, 43 Y ALE L. J. 227 (1933).

4S. See Gresnwood v. Leather Shod Wheel Co., [1900] 1 Ch. 421 ; Broome v. Speals, [1903] 1 Ch. 586; Central Railway Co. of Venezuela v. Kisch, L. R. 2 H. L. 99,113 (1867). But see In re Christineville Rubber Estates, 81 L. J. Ch. 63 (1911). 
the Report. The latter would extend civil liability to statements in prospectuses which are misleading by virtue of factual omissions that were known or could have been known upon reasonable inquiry. ${ }^{49}$

If misleading statements by experts are included in a prospectus, not only would directors and promoters have the burden of justifying their reliance, but the experts themselves, if their consent was obtained, must prove reasonable ground's for believing the truth of their statements. ${ }^{\text {it }}$ Bankers and solicitors, however, whose names may be listed prominently in the prospectus, would not be subject to this liability. ${ }^{52}$ The British provisions are aided by judicial interpretation that reliance on the false statements necessary in civil actions need not be induced by any specific statement in the prospectus. ${ }^{53}$ The Securities Act in Section 11 similarly omits reliance in the event the issuer has not, prior to purchase, made public an earnings statement, but Section 18 of the Securities Exchange Act and Section 16 of the Public Utility Holding Company Act do make reliance a part of the plaintiff's cause of action. ${ }^{54}$

Non-par Stock. In contrast to the American practice of allowing shares of no par value, the Companies Act now requires that the charter must state the amount of share capital of the company and that every provision in the charter, by-laws, or in any resolution purporting to divide the enterprise into shares shall be treated as a provision for share capital. ${ }^{65}$ In failing to recommend a departure from present law, the Committee gave consideration both to the lack of public demand for non-par stock and to the elaborate legislative and administrative supervision which might well reintroduce most of the complications which non-par stocks are designed to avoid. ${ }^{50}$

Disclosure of Beneficial Ownership. The problem of "nominee shareholdings" was one of the most baffling to which the Committee directed its study.

49. REPORT $\$ 36$ and p. 20. No mention is made of knowledge by the vendee of the untruth or omission as a defense. See Secuniries Acr $\S 11$ (a). With the recommenda tions of the Committee compare the parallel suggestions of SAMUEL, op. cit. supra note 26, at 23-31.

50. Under $\$ 11(b)(3)(C)$ of the Securities Act the defendant must prove "he had no reasonable ground to believe and did not believe" the statements were misleading. Under the English amendment, the defendant must prove that "he had reasonable cause to .rely" on the expertization. REPORT pp. 24-5.

51. Report p. 25. Cf. Securities Acr §11(b) (3) (B).

52. REPORT $\$ 46$.

53. Compare Arnison v. Smith, 41 Ch. D. 348, 369 (1889) with Macleay v. Tait, [1906] A.C. 24. See Shulman, supra note 47, at 249.

54. See Washington, Corporate Executives' Compensation 361 (1942). With the shift of the burden of proof in criminal cases as well as civil, opportunity for restrictive interpretations of these provisions would appear minimized. See infra pp. 1395-6. Cf. . Shonts v. Hirliman, 28 F. Supp. 478 (S.D.Cal. 1939).

55. Companies Act $\S \S 2(4), 21$.

56. Report \$\$17-8. See Berle, Problents of Non-Par Stock, 25 CoL. L. Rev. 43 (1925) ; Wickersham, Stock Without Par Value (1927); 1 Dewinc, Tue FinaisCias Policy of Corporations 70-6 (4th ed. 1946). 
As reasons for requiring disclosure of beneficial stock ownership, proponents stressed the desirability of exposing actual or potential foreign control over essential British industries and the advantages to domestic stockholders and creditors of locating the precise seat of corporate control. ${ }^{87}$ On the other hand, the nominee system is extremely popular and serves useful and convenient functions for residents outside the United Kingdom and for executors and trustees under wills. ${ }^{53}$ While endorsing the principle of complete disclosure, ${ }^{59}$ the Committee found suggested reforms to "involve a volume of work out of all proportion to the probable benefits to the public." The Committee therefore limited itself to compromise measures. Beneficial ownership is defined in terms of (a) absolute ownership of a share, (b) power to transfer a share absolutely or conditionally, or (c) power to control a share's vote directly or indirectly. ${ }^{60}$ Transferees of shares would be required to state whether or not they are the beneficial owners thereof and beneficial owners of $1 \%$ or more of any class of capital stock must disclose such interest in books to be made available for inspection. ${ }^{61}$ In terms of practical effect, however, the most important recommendation utilizes the administrative machinery of the Board of Trade by giving it sweeping powers to investigate transactions where it is desirable or in the public interest to disclose beneficial ownership. ${ }^{62}$

\section{DrRECTORS}

The increasing gulf between widely distributed ownership and control is

57. Public knowledge of who controls the press and the advantage in facilitating shareholder communications were also emphasized. REFORT \$79.

58. Approximately 600,000 individual holdings were registered in the names of bants of the British Bankers' Association in 1943. One bank analyzed its holdings as follows: $18 \%$ for residents outside the United Kingdom; $8 \%$ for stock exchange brokers; $4 \%$ for insurance and trust companies; $8 \%$ to facilitate purchases and sales and for convenience due to absence abroad; $50 \%$ for executors and trustees under wills; $11 \% \circ$ as security ; unidentified purposes included less than 1\%. More than the last group, of course, could embrace concealment. Other figures indicate a turnover of almost four times per year per share held. REPORT $\S 78$.

59. REPOXT $\$ \$ 0$. "Our doubts are on the question of enforceability." Layers of trusteeship may become multiple in many cases before real beneficial ownership is reached. The Committee notes possible methods of evasion were a flat prohibition of registration in the names of nominees adopted. Ibid.

60. RFPORT p. 49. As to whether this definition includes "trustees" or "mortgagees" see 200 L.T. 58 (1945); 89 Soc. J. 538-9 (1945).

61. REPORT $\$ \$ 81-2$. Schedule A(6) of the Securities Act requires the identifieation, when known, of all persons beneficially owning $10 \%$ of any class of stock or $10 \%$ in the aggregate of outstanding stock. See also $\$ 10$ (a) (1)(C) of the Public Utilities Holding Company Act (identification of persons owning or controlling $1 \%$ or more of any class of securities).

62. The Committee characterizes these powers as "drastic." The Board of Trade would have power to appoint an inspector to investigate ownership, and to direct the company to deny the exercise of any rights, including dividends, attached to shares under question. REPORT $\$ \S 84-5$ and p. 45. 
an economic fact of corporate evolution. Directors, increasingly "managers rather of other people's money than of their own," ${ }^{63}$ assume a trustee as well as an administrative function. ${ }^{64}$ On this problem the Report makes a number of recommendations, the cumulative effect of which not only would impose higher levels of director responsibility but also make public many of the financial relations between companies and their directors.

Responsibility. In the problem of loans, the Committee has squarely met the dual motivations posed by a conflict between a director's self-interest and his duty. While Section 128 of the present Companies Act controls the borrowing of a director or officer from a company only to the extent of disclosing certain details in the accounts, the Report includes, as do many of our state laws, ${ }^{65}$ a flat prohibition of such loans. In a broader formula, however, than that of our state law counterparts, the prohibition would extend, as in the Investment Company Act of 1940 , to loans by subsidiaries to directors of parent companies or "under guarantee from or on security provided by" the corporation or controlled interests. ${ }^{66}$

The Report proposes that a new section be added to the Companies Act, dealing with transactions by directors in company stock, but is unable to advance more than its standard solution of complete disclosure of any direct or indirect interest in stock or debentures. ${ }^{67}$ Three of our federal enactments administered by the Securities and Exchange Commission go considerably further in permitting redress for abuse of inside information. For disclosure, however, the Securities Exchange Act and the Investment Company Act require ownership of $10 \%$ of stock of any class. ${ }^{68}$

The Companies Act at present requires that a director reveal his interest in material contracts either at a directors' meeting or by general notice to

63. Adam Smith, Wealth of Nations, Bk. V, Ch. I, pt. 3, Art. 1 (1776).

64. "... . when the history of the financial era which has just drawn to a close connes to be written, most of its mistakes and its major faults will be ascribed to the failure to observe the fiduciary principle ... that 'a man cannot serve two masters." Stonte, Public Influence of the Bar, 48 Harv. L. Rev. 1, 8 (1934).

65. See, for example, Del. Rev. Code $\$ 2068$ (1935) ; N.J. Stat. Ann. $\S 14: 8-10$; Ohio Gen. Code § 8623-123a (Page, 1937); Wulfjen v. Dolton, 24 Cal.2d 878, 151 P.2d 840 (1944). For other problems on loans to directors, see Rubinstein v. Kasprzak, 96 N.J.Eq. 406, 124 Atl. 362 (Ct. Err. \& App. 1924) ; Lindemann v. Rusk, 125 Wis. 210, 238, 104 N.W. 119, 128 (1905); Statenent on Life Insurance 57 (TNEC Monograph 28-A, 1941).

66. Report p. 51. Cf. Investment Company Acr $\$ \$ 17,21$. See Report of the Stockholders Investigating Committee of the Texas Corporation, discussed in Douglas, Dircctors Who Do Not Direct, 47 HARv. L. REv. 1305, 1309-10 (1934) (total loans to officers and employees of $\$ 2 \mathrm{t} / 2$ million).

67. The proposals appear wider than those for nominees. See p. 1393 supra. Books recording directors' stock transactions and holdings would be available to sharcliolders before the annual meeting and to the Board of Trade at any time. REport pp. 50-1.

68. Securities Exchange Act $\$ 16(\mathrm{~b})$, Public Utility Holding Company Act $\S 17(\mathrm{~b})$, and INVESTMENT COMPANy ACT $\$ 30(\mathrm{f})$ permit suits by or on behalf of the issuer to recover insider's profits on purchase and sale of the corporation's securities within six 
other directors. ${ }^{69}$ The London Stock Exchange Council in addition places limitations on the classes of contracts upon which a director, if personally interested, may vote. ${ }^{70}$ These sanctions are modified only by making the notice of interest a part of the recorded minutes of the directors' meetings. ${ }^{71}$ The Committee declined to write into legislation a proposed judicial solution that all transactions in which interested directors have participated are voidable. ${ }^{72}$ Such a general prohibition was considered impracticable both because the permutations of directors' interest could not adequately be anticipated by legislation and in some cases a quorum of disinterested directors would be rendered impossible. ${ }^{73}$

Criminal sanctions against directors have been strengthened in one important respect. At present, the prosecution must prove the falsity of a statement in a prospectus and, in addition, the director's knowledge of the falsity. ${ }^{74}$ The Committee recommended that the burden of proof be shifted to the director to show that he did not and could not, by reasonable precautions, know of the misstatement. ${ }^{75}$ Such a measure was discussed in hearings on the Securities Act but rejected as "contrary to the principle of American jurisprudence that guilt is never to be presumed." 30 Although precedent exists in this country as well as in England 77 for a statutory shift of the burden of proof in criminal cases, American courts have been insistent upon looking to the rational probabilities of the presumption as determinative of its constitutionality. ${ }^{\text {is }}$ The Committee expressly states that, in their

months. The cited section of the Securities Exchange Act applies to "equity" securities, while the Public Utility Holding Company Act and the Investment Company Act are not similarly limited.

69. Courpanies Act $\$ 149$.

70. REPORT $\$ 95$.

71. REPORT $\$ 95$ and p. 52.

72. British decisions have been particularly inclined to void transactions in which directors had personal interest. See cases collected in BALlanisine, ConfosAtons \$67 (1946). See also SEC v. Chenery Corp., 318 U.S. 80, 92 (1943): "Abuse of corporate positions, influence, and access to information may raise questions so subtle that the law may deal with them effectively only by prohibitions unconcerned with the faimess of a particular transaction."

73. Thus, the company may merely be considering a shipment of goods by a railrosd in which a director held some stock. A contract between a parent and subsidiary in which the boards are identical provides an example of the lack of a quorum of disinterested directors. REPORT $\$ 95$.

74. Prosecutions are normally brought under $\$ 84$ of the Larceny Act, 1851, $24 \& 25$ VICT., c. 96. REPORT $\$ 41$.

75. REPORT $\$ 41$ and p. 25.

76. See Hearings before Conmittee on Banking and Currency on S. Res. S4, S. Res. 56, and $S$. Res. 97, 73d Cong., 1st Sess. 6840, 7227 (1934).

77. For English precedent, see Refort \$41. For American precedent compare Casey v. United States, 276 U.S. 413 (1928); Yee Hem v. United States, 26S U.S. 178 (1925); Adams v. New York, 192 U.S. 585 (1904); Hawes v. Georgia, 258 U.S. (1922), rath Tot v. United States, 319 U.S. 463 (1943).

78. See cases cited note 77 supra. 
opinion, a proven false or misleading statement is sufficiently exceptional to warrant the presumption. ${ }^{79}$ The British proposal, however, appears motivated more by the important in terrorem influence of the law than by administrative considerations such as the facilitation of proof.

One unchanged provision of the Companies Act deserves consideration along with the many revisions of the Report. Non-managing directors, whose position has been emphasized in British business custom, often bring to their job interests sufficiently detached from the managing side of the board to provide in a real sense independent supervision and another facet of stockholder representation. ${ }^{80}$ However, the different functions of the two types of directors are accorded no appreciable recognition in United States law. Indeed, non-managing directors may be at a disadvantage, since they are in no position to satisfy the detailed standards which our federal enactments put on them. England recognizes the distinction by imposing a different standard of liability. Among the circumstances against which director's responsibilities are to be judged the Companies Act includes "those connected with his appointment." 81

Compensation. The compensation of directors, an issue of increasing importance in the light of rising tax rates and the greater dependence on salaries, is treated in three recommendations. Perhaps motivated more by disapproval of a group uniquely immune from increases in taxation than by the necessity of effecting a practical solution to the difficulties "tax-free" remuneration provide, ${ }^{82}$ the Committee has proposed an outright prohibition of the practice whereby a company assumes the tax burden on directors' salaries. ${ }^{83}$ An additional reason advanced for removing "tax-free" salaries from the ambit of stockholders is the difficulty that stockholders would have in determining the cost of management, since the charges to the corporation would vary with the director's total income. ${ }^{84}$

79. REPORT $\$ 41$.

80. See Douglas, stipra note 66; 5 U. Chr. L. REv. 668 (1938). But scc SAMuEt, op. cit. supra note $26, \mathrm{c} . \mathrm{V}$.

81. Companies Act \$371(1). See Report of the Englisu Company Law AnendMIENT CoMmitree $\$ 47$ (1926). The clause has drawn favorable American comment. Sce Douglas, supra note 66, at 1328; 5 U. CHr. L. Rev. 668, 672-4 (1938).

The controversial recommendation is also made that directors be removable by ordinary resolution rather than the $75 \%$ of those voting now required in Table $\mathrm{A}$ of the Companies Act. REPORT $\S 130$ and p. 84.

82. For treatment of the tax problem, compare Old Colony Trust Co. v. Commissioner, 279 U.S. 716 (1929) with Michelham's Trustees v. Commissioners of Inland Revenue, 144 L. T. R. 163 (C.A. 1930).

83. REPORT $\S 88$ and p. 52 . In one state of this country "tax-free" salaries are similarly prohibited. Twenty-seven years after enactment, Section 385 of the New York Tax Law, which voids all agreements "directly or indirectly to pay or assume to bear" taxes payable under the law, has been interpreted to invalidate agreements to carry taxes on executive salaries. Reiss v. Reiss, 186 Misc. 511, 59 N.Y.S.2d 828 (Sup. Ct. 1945).

84. However, some compensation schemes may actually effect a saving to the corporation. See WASHINGTON, op. cit. supra note 54, at 129. 
Though the same moral outlook is evident in its approach to disclosure of directors' remuneration, ${ }^{85}$ the Report does not recommend full disclosure of the individual compensation of company officials. The function of disclosure is conceived to be only that of accounting for "director overhead," the aggregate amount of which can be measured by the shareholder against the value of director services as a whole. ${ }^{\varepsilon 0}$ And since it is only directors who are their own keepers, other executives would not be included under this provision. ${ }^{\$ i}$ For accounting purposes, remuneration would be carried as a separate item on the profit and loss account, but pension schemes would not be, since included as remuneration in the year to which they are charged. ${ }^{85}$

American legislation in this field was given impetus during the depression by public reaction to stockholder suits and federal investigation which had revealed disproportionately large executive salaries. ${ }^{\natural}$ The Securities and Exchange Commission now has requirements for disclosure of individual and aggregate incomes that go considerably further than the British proposals. ${ }^{30}$

A third aspect of the remuneration problem is presented when directors are specially compensated for loss of office. The case law of Great Britain has until recently dealt leniently with retirement bonuses to directors, ${ }^{01}$ a practice which the Report proposes to permit only upon express approval at

85. The Companies Act now provides for disclosure of all "emoluments" to dircetors but excepts managing directors-a proviso that occasionally has resulted in entire boards of "managing directors." CosipanIEs ACT $\$ 128(3)$. REPORT $\$ 89$.

86. REPORT $\$ 90$ and p. 52, thus repealing $\$ 148$ of the Companies Act. No specific change in the provision for managing directors is suggested.

The Committee also recommends that "emoluments" be defined to include all allowances which are assessed as income to the director for tax purposes. Rerost $\$ 90$ and p. 52.

87. The Committee rejected a proposal that incomes of exceutives over a statcd amount be disclosed. REPORT $\$ 90 ; c f$. American requirements infra note 90 .

88. Report p. 62.

89. See, for example, Rogers v. Hill, 289 U.S. 582 (1933) ; Rogers v. Guaranty Trust Co., 288 U. S. 123 (1933). WaSHrNGton, op. cit. supra note 54, c. 14.

90. SecurtTIES ACT, Schedule A(14) requires the identification of officers whose remuneration is $\$ 25,000$ or over yearly. Form $10-K$, pursuant to $\$ 13$ of the Securities Exchange Act, requires the identification of persons in three highest aggregates of remuneration. It also requires disclosure of the aggregate of remuneration of all directors, all officers, and employees receiving over $\$ 20,000$ a year. See Secunities Exchasice Act, \$12(b) (1) (D),(E) and (F), SEC General Rules AND Regulitions Utider tHe SEcurities Exchange Act of 1934, Schedule 14A, esp. items 5 and 9; Public Utuit: Holding CoMrpany ACT \$ 5(b) (2) (D) and (E); Investarest Cosspa:iY ACt \$ \$(b) (4). See also Wasmington, op. cit. supra note 54, at 226-36.

91. Compare Cyclists' Touring Club v. Hopkinson, [1910] $1 \mathrm{Ch} .179$ ztith Associated Portland Cement Mffrs., Ltd. v. Inland Revenue Commissioners, [1946] 1 All Eng. 6S (C.A.) American decisions on retirement bonuses have been less liberal. See cases collected in Notes, 40 A.L.R. 1423, 1440 (1926); \&8 A.L.R. 751, 755 (1934).

The Committee also recommends that a retiring age for dircetors be fised at 70 to be effective automatically unless stayed by special resolution. REFOnT $\S 131$. 
a general stockholder meeting with all circumstances revealed. ${ }^{92}$ Compensation for loss of office attendant upon a transfer of controlling interests in stock, a recurring English problem, would be illegal unless ratified by stockholders of the classes affected. ${ }^{93}$ Money or stock acquired by directors violating these provisions would be deemed to have been received in trust. ${ }^{94}$ The Report does not comment on the important American problem of the indemnification of directors against litigation expenses arising out of unjustified charges.

\section{StockHolders' ConTrol}

The other phase of involute corporate control is ownership vested in dispersed, small, absentee shareholdings. While nominally at least, the greatest safeguard against oppression lies in the right to vote, stockholders have yet to be welded into an effective, articulate, and democratic body. The Committee directs its attention to practical provisions which can afford aggressive minority stockholders means to express their ideas and to organize some measure of support for them.

Proxies. The proxy system-lifeline of corporate control-poses simultaneously the greatest opportunities for democratic participation in corporate management and for wide-scale abuse. ${ }^{95}$

As a first step in controlling proxies, it is recommended that the notices of meetings be accompanied by a clear statement that non-stockholders as well as stockholders may be appointed as proxies. ${ }^{96}$ Company by-laws which have restricted this privilege to stockholders confine materially the choice of representatives. Indeed, such a restriction may leave the stockholder a

92. The exception recognizes situations in which it is to the corporation's interest to negotiate a resignation rather than face legal proceedings after dismissal. REporr \$ 92(a) and p. 52. Cf. Winkelman v. General Motors Corp., 44 F. Supp. 960, 974 (S.D.N.Y. 1942).

93. Report § 92(b) and p. 52. See Hulton v. West Cork Ry. [1883] 23 Ch. D. 654, 684.

When any offer is made to a company to purchase stock or assets, the proportion of the offer that would be diverted under the name of compensation to directors would be approved by those receiving the balance of the offer. Any advantage received by a director within one year before or two years after an offer was accepted would be deemed to be in contemplation of the offer unless the director can show the advantage would have accrued independently. REPORT \$92(b) and pp. 52-3.

94. Redistribution would be at the director's expense. Report \$92(b) and p. 53.

95. The Committee's recommendations on proxies are also important because the Companies Act of 1929 only referred to the problem in minor provisions of Table A. The amendments are thus designed to override by-laws to the contrary.

96. Report $\$ 132$ and p. 85. See People's Home Savings Bank v. Superior Caurt of San Francisco, $104 \mathrm{Cal}$. 649, 38 Pac. 452 (1894) (right to appoint non-stocktholder as proxy even if forbidden by by-laws). But sec Colonial Assurance Co. v. Smith, 22 Manitoba L.R. 441 (1912). Other cases have not taken so explicit a stand. Sec also GentryFutch Co. v. Gentry, 90 Fla. 595, 609, 106 So. 473, 478 (1925). 
choice of renouncing his vote or ratifying the management proxies. 0 The recommendation would make available as proxies independent professional advisors and thus aid the absent stockholder by substituting expertise for the average stockholder's unfamiliarity with the intricacies of corporate affairs and by creating a professional group to scrutinize management policies.

There is no statutory obligation in either England or the United States to mail proxy forms to stockholders. The Report, however, would require the inclusion of a statement of the right to proxy with notice of meetings. ${ }^{\text {?3 }}$ Furthermore, proxy forms, if issued at company expense, must be distributed to all stockholders. The proposed obligation is to be contrasted with a recent English case in which only holders of 2500 or more pounds' worth of stock received forms from the company, while smaller stoclhholders, left to shift for themselves, had many home-made proxy forms disqualified by irregularities. Such preferential methods were held to be a question of policy for the company that was legally unassailable unless prohibited by the charter. ${ }^{\circ 3}$ The principle of equality of rights for proxies would extend to their right to speak and demand polls at meetings as well as vote. ${ }^{100}$ And principals would be able to direct their proxy to split their stock for voting on both sides of an issue. ${ }^{101}$

The Committee also discussed the suggestion urged upon them that proxy forms be so worded that members, by a form of referendum, may vote for or against resolutions separately. A similar practice is presently required by the London Stock Exchange Council whenever special business is transacted. ${ }^{102}$ The conclusion of the Committee, however, is that neither this suggestion nor one to give a proxy discretionary voting powers is a practicable legislative matter. ${ }^{103}$

The proxy requirements under Section 14 of the Securities Exchange Act are among the most important of our federal regulations. ${ }^{108}$ The Securities

97. See People's Home Savings Bank v. Superior Court of San Francisco, 104 Cal. 649, 38 Pac. 452 (1894).

98. REPORT $\$ 132$ and p. 85.

99. Wilson v. L.M.S. Ry. [1940] 1 Ch. 393; see also Peel v. L. and N.W. Ry. [1907] 1 Ch. 5. Cf. Hand v. Missouri-Kansas Pipe Line Co., 54 F. Supp. 649, 651 (D.C. Del. 1944) (discussing the advantage of the management in having paid prosy solicitors and declaring that it is not a function of the court to keep factions on equal financial footing).

100. REPORT p. $87 . \$ 117$ (4) of the Companies Act is to be modified to provide that any five stockholders, or any group aggregating one-tenth of the voting rights may demand a poll on any resolution. See Second Consolidated Trust, Ltd. v. Ceylon Amalgamated Tea and Rubber, Ltd. (1943) 2 All Eng. 567.

101. REPORT $\$ 135$ and p. 85 .

102. REPORT $\$ 132$.

103. Such matters are left to the discretion of the London Stock Exchange Council, "which can waive or modify them in suitable cases." Ibid.

104. These proxy rules are incorporated by reference in the Public Utility Holding 
and Exchange Commission specifically requires that proxy solicitations permit a choice between approval or disapproval of each matter to be acted upon by the proxy, and it sanctions the conferring of blanket discretionary authority for matters unanticipated by the solicitor. ${ }^{105}$ The Commission has significantly utilized proxy solicitations as a means of presenting information to the stockholder and requires detailed disclosure of the interests bchind the solicitation, and of the particulars of the transactions to be acted upon. ${ }^{106}$ Proxy regulations, however, may now be avoided simply by not soliciting proxies. To remedy this major defect, the Commission has recommended that Section 14 be amended to require issuers to submit the information required by the proxy rules before corporate meetings. ${ }^{107}$

Equality of representation by proxy and knowledge of individual rights lose their efficacy without means of communication between stockholders to organize blocks of opinion. The Cohen Committee thus proposes that 100 stockholders holding on the average not less than $£ 100$ of paid-up stock, or stockholders with $5 \%$ or more of the voting stock shall be entitled to send out with the notice of the annual meeting a 1000 word statement of proposed resolutions. Notice of the resolutions would be made to the company within 35 days of the meeting, and a right to require distribution by the company of a 1000 word comment on matters to be transacted would be present from the time of notice of the meeting until seven days thereafter. ${ }^{108}$ Time allowances for communications would be supplemented by restricting the period in which proxy returns could be required in advance of the meetings to 48 hours. ${ }^{109}$

Under the Securities Exchange Act management is obligated to include with proxy solicitations proposals which stockholders give notice of intending to present for action at the meeting and, if such proposals are opposed

Company Act $\S 12(e)$ and Rule U-61; and in the Investment Company Act $\$ 20$ and Rule N-20A-1. These sections make proxy solicitation unlawful through the use of any interstate instrumentality or the mails unless in accordance with rules prescribed by the Securities and Exchange Commission.

105. See Rule $X-14 A-2$ under the Securities and Exchange Act.

106. Every proxy solicitation must include the information required in Schedule 14A, and, if directors are to be elected, an annual report to security holders. Rule X-14A-1. For discussions of the proxy regulations see Dean, Non-Compliance tuith Proxy Regntlations, 24 CoRs. L. Q. 483 (1939) ; Axe, Corporate Proxics, 41 Micn. L. Rev. 38, 225 (1942) ; Bernstein and Fischer, The Regulation of the Solicitation of Proxics, 7 U. Cur. L. Rev. 226 (1940) ; Comment, 33 Iri L. Rev. 914 (1939); Notes, 53 Hasv. L. Rev. 1165 (1940), 13 ST. JoHN's L. REv. 297 (1939).

107. Report of the Securities and Exchange Commission on Proposals for Amendments to the Securities Act of 1933 and the Securities Excinange Act of 1934, 77th Cong., 1st Sess. 35 (1941). Proposal to Safeguard Investors, H. R. Doc. No. 672,79 th Cong. $2 \mathrm{~d}$ Sess. 17-20, 31 (1946) recommends extending proxy regulations to securities of unregistered companies of at least $\$ 3,000,000$ in assets and 300 security holders.

108. REPORT $\S 128$ and p. $85-6$. The seven day limitation is imposed to allow clirectors to circulate answers to any criticism.

109. REPORT $\$ 134$ and p. 84. 
by the management, to distribute a statement of 100 words at the stockholder's request. ${ }^{110}$ Under the Commission's rules, the management must anticipate which proposals are "proper subjects for action by the security" holders" or render the solicitation "false and misleading in a material respect," Inl while the British amendment places the responsibility for the substance of communications upon the stockholder. As a second point of difference it will be noted that all cost of distribution of communications under the British scheme would be borne by the company except for printing, and even that on occasion subject to reimbursement by the company, ${ }^{112}$ whereas the Securities and Exchange Commission permits independent solicitation but places the not inconsiderable cost of such communications on the stockholder. ${ }^{113}$ As sanctions the Report would use discretionary fines on each responsible person, one of the few techniques not included in the arsenal of SEC regulations. ${ }^{114}$

Meetings. To the extent that disclosure requirements are intended to provide information essential to an appraisal of management operation and policy, it is largely to corporate meetings that they are ultimately directed. If the meetings are postponed, held in inaccessible places, or if stockholders are ignored by a withholding of notice, their right of participation has been correspondingly abrogated. ${ }^{115}$

110. Rule X-14A-7. Notice 30 days in advance of a date corresponding to the proxy solicitations of the previous year is prima facie reasonable notice of a proposal. Ibid. See also Rule X-14A-6; Trust Indenture Acr §312, 53 Stat. 1149 (1939), 15 U.S.C. $\S 77 a a(1940)$.

111. Rules $X-14 A-5$ and 7. For complications under the SEC rules, see Dcan, supro note 106 , at $497-517$. Rule $X-14 A-7$, however, relates only to matters which are appropriate subjects for stockholder action under state law, and not in obtaining expressions of a stockholder's political, social or cconomic views. Sec Securities Exchange Act Release No. 3638, Jan. 3, 1945.

112. If a general meeting of the company so resolves, the printing costs would be refunded. REPORT $\$ 128$ and p. 86 .

113. Rule X-14A-6. Cf. Wilson v. L.M., and S. Ry. [1940] Ch. 393, 395 (difierence in cost between partial and total solicitation that of $£ 250$ and $\$ 4000)$.

114. Fines range from \pm 50 (failure to notify of right to proxy) to 1100 (preferential distribution of proxy forms) and \pm 500 (breach of communication provisions) for each responsible officer or director knowingly a party to the default. REFost pp. 85-6.

For the variety of remedies available to the Securities and Exchange Commission, see SEC v. Okin, 139 F.2d 87 (C. C. A. 2d 1943) (injunction to restrain violation of rules); Wyatt v. Armstrong, 186 Mise. 216, 59 N.Y.S.2d 502 (Sup. Ct. 1945) (election of direetors set aside) ; SEC v. Okin, 58 F. Supp. 20 (S.D.N.Y 1944) (injunetion to restrain use at annual meeting of proxies obtained in violation of rules); SEC v. Otin, 132 F.2d 784 (C.C.A. 2d 1943) (power to regulate proxies extends to writings part of a continuous plan ending in solicitation; inclusion of a statement necessary to prevent assertion being false or misleading).

115. Report $\$ 127$; Sie Walsh v. State, 199 Ala. 123, 126, 74 So. 45,47 (1917) ; Mottu v. Primrose, $23 \mathrm{Md}$ d. 482 (1865) ; cf. Jones v. Mforrison, 31 Mínn. 140, 149-50, 16 N.W. 854,859 (1883). 
The Companies Act provides for 7 days' advance notice of annual general meetings. ${ }^{116}$ As the Committee finds this period insufficient for the desired full exchange of individual viewpoints, it would extend the period to 21 days for the general meeting and 14 days for other meetings. In emergencies, however, the 14 day period could be waived by $95 \%$ of the voting stock and the 21 day period by unanimous consent. ${ }^{117}$

Touched only indirectly by federal enactments, ${ }^{118}$ notice of mectings has received far from uniform treatment in state legislation. In states where notice was not required by statute, it has been held, perhaps unrealistically, that the stockholder will be presumed to know the time and place of meetings specified in the by-laws, and hence is not entitled to actual notice. ${ }^{110}$ Where notice is required by statute but no period specified, the notice must be reasonable, ${ }^{120}$ but a period of as little as five days has been held sufficient. ${ }^{121}$ If the purpose of statutes requiring notice is to insure the opportunity of the stockholder to attend or to communicate his ideas, the English period, or the 10 days required by the Model Business Corporation Act would appear the minimum practical. ${ }^{122}$

\section{CONCLUSION}

Public reaction to the Report has reflected a high degree of approval for its technical competence. The timeliness of a major post-war revision is emphasized by the nationalization of many industries, and a consequent reloca-

116. CoMpanies Act § 115(1); Report § 126.

117. REPORT $\S 126$ and p. 86 . The Committee also would clarify a minor point of case law by providing that one shareholder can under proper circumstances constitute a "meeting." See Morrill v. Little Falls Mfg. Co., 53 Minn. 371, 55 N.W. 547 (1893). Contra: Sharp v. Dawes, [1876] L.R. 2 Q.B.D. 26.

118. See, for example, Rule X-14A-1(b), furnishing some advance notice of mectings through the requirements for annual statements.

119. Warner v. Mowrer, 11 Vt. 385 (1839).

120. See In the Matter of Long Island R.R., 19 Wend. 37 (N.Y. 1837); Taylor v. Grisword, 14 N.J.L. 222 (Sup. Ct. 1834).

121. Moon v. Moon Motor Car Co., 17 Del. Ch. 176, 151 Atl. 298 (Ch. 1930).

122. Model Bustness Corporation Act $\S 27$. The period of notice prevailing in this country is considerably below the 21 days advanced by the Committee. Some states permit a 10 to 40 or 45 day period. Ill. Rev. Stat. c. 32, $\$ 157.27$ (Smith-Hurd, Supp. 1946); New York Stock Corporation Law §45; Ohio Gen. Code \$8623-44 (Page, 1937). Many, however, require less than 10 days; Mass. Laws ANv. c. $156, \S 28$ (1932) (7 days); PA. Stat. Anv. tit. 15, \$2852-502 (Purdon, 1930) (5 days). Delaware apparently does not require notice except when the provisions in the by-laws concerning meetings are changed. Des. Rev. Code $\$ 2062$ (1935). Mich. St八t. AnN., c. 195, $\$ 21.39$ permits notice to be as provided in the by-laws.

It would appear that short periods of notice under state statutes or by-laws would materially decrease the opportunity for communications between stockholders made possible, for example, by Rule X-14A-6, under the Securities Exchange Act. It is possible, however, that an exploitation of the short periods of notice to avoid the proxy rules on communications could be enjoined. See note 114 supra. 
tion of investment of which a substantial amount will probably be from fixed securities to stocks.

The Report, by excluding discussion of two issues, has lessened its reference value. Company law has been defined largely by legislation without adequate discussion of continuing administrative control by an independent administrative agency similar to the Securities and Exchange Commission. ${ }^{123}$ And a substantial accounting revision has been undertaken without a clarification of the basic legal issues involved in dividend law and the evaluation of assets. Criticism of the amendments, as presented to Parliament, ${ }^{128}$ has also been directed to the Committee's reluctance to abandon traditional methods for more spectacular solutions to corporate problems. ${ }^{125}$

While this innate moderation of approach may, in the testing ground of British corporate practice, prove either a strength or a weakness, the Reporl's delicate balancing of objectives, thoroughness, and attention to detail implement its value as a legislative program and as a reference for many years in the reconsideration of American laws.

123. See REPORT $\$ 176$; $\$ 9$ SoL. J. 473 (1945). Administrative control by the Board of Trade has been increasingly stressed as the Bill progresses through Parliament. See 148 H.L.DeB. 958 (No. 54 1947) ; 438 H.C.DEB. 598, 611, 63S (5th Ser. 1947).

124. The new Companies Bill passed the House of Commons as this article went to press. See 441 H.C.DEB. 172 (5th 1947). Surprisingly, the recommendation on the ultra vires doctrine was omitted from the bill. See 202 L.T. 319 (1946).

For modifications made in the House of Lords, who first considered the Bill, see 148 H.L.DEB. 955 (No. 54 1947).

125. See 149 The Econousst SS, 126, 234, 372 (1945); 81 Tue Baiker 21, 26 (1947), 89 SoL. J. 53S-9, 526-7; 53S-9, 548 (1945). Cf. Kahn-Freund, stpra note 11; 148 The EConomist 185, 186 (1945). 